\title{
Immunohistochemical analysis of p53 expression in anal squamous neoplasia
}

\author{
O A Ogunbiyi, J H Scholefield, J H F Smith, S V Polacarz, K Rogers, F Sharp Abstract
}

University

Department of

Surgery,

Northern General

Hospital, Sheffield

O A Ogunbiyi

J H Scholefield

K Rogers

University

Department of

Obstetrics and

Gynaecology

F Sharp

Department of

Histopathology

J H F Smith

University

Department of

Pathology, Medical

School, Sheffield

$S$ V Polacarz

Correspondence to:

$\mathrm{Mr} O \mathrm{O}$ Ogunbiyi

Department of Surgery,

Clinical Sciences Centre,

Northern General Hospital,

Herries Road, Sheffield

S5 7AU

Accepted for publication

27 November 1992

\begin{abstract}
Aims-To determine the pattern of expression of the p53 tumour suppressor gene product in anal squamous neoplasia, and to determine if this could be used as a marker of disease progression. The association between $p 53$ expression and human papillomavirus (HPV) 16 DNA status of the anal lesions was also investigated.
\end{abstract}

Methods-The presence and localisation of the p53 protein in formalin fixed, paraffin wax embedded specimens of anal squamous epithelium (normal and neoplastic) was examined using immunohistochemical staining with a panel of two monoclonal antibodies (DO-1, DO-7) and one polyclonal antibody (CM-1). Thirty nine normal anal epithelia, 14 anal intraepithelial neoplasia (AIN) grade 1, seven AIN 2, and 20 AIN 3 specimens were obtained from patients without demonstrable invasive disease; twelve AIN 3 specimens adjacent to invasive disease and 34 anal squamous cancers were also examined. Genomic DNA from all 126 specimens was extracted and analysed for HPV 16 DNA using the polymerase chain reaction (PCR).

Results-Nuclear p53 was strongly expressed in $67 \%(23 / 34)$ of invasive anal squamous tumours, $75 \%(9 / 12)$ of AIN 3 specimens adjacent to invasive disease, and in $60 \%(12 / 20)$ of AIN 3 specimens obtained from patients without demonstrable invasive disease. Two of the patients in the latter group with positively staining specimens subsequently developed invasive tumours which had staining characteristics similar to those of the AIN 3 specimens. p53 protein was expressed in very low concentrations in low grade AIN and not at all in normal anal squamous epithelium. In those specimens which stained positively for p53, HPV 16 DNA sequences were detected in $69.5 \%(16 / 23)$ of invasive disease, $77 \cdot 7 \%$ (7/9) of AIN 3 adjacent to invasive disease, $75 \%(9 / 12)$ of AIN 3 obtained from patients without demonstrable invasive disease, $33.3 \%(2 / 6)$ of AIN 2, and in $40 \%(2 / 5)$ of AIN 1. There was no significant correlation between p53 immunostaining and HPV 16 DNA status $(p<0.05)$.

Conclusions-Aberrant expression of the p53 gene product is probably involved in the pathogenesis of anal squamous neoplasia. Long term follow up studies of all patients with AIN are required to determine if this could be used as a marker of likely disease progression from high grade AIN to invasive disease. There does not seem to be an association between the presence or absence of HPV 16 DNA sequences and mutant p53 proteins in anal squamous neoplasia.

$(7$ Clin Pathol 1993;46:507-512)

Current evidence implicates human papillomavirus (HPV) infection, particularly types 16 and 18, in the pathogenesis of anogenital squamous neoplasia. ${ }^{12} \mathrm{HPV}$ DNA sequences have been shown to be integrated in the human genome in $75-90 \%$ of invasive anogenital squamous tumours. Other cocarcinogens, however, are likely to be involved in the pathogenesis of anogenital neoplasia. ${ }^{3}$ Alterations in the structure and expression of cellular oncogenes have been shown in cervical and anal squamous neoplasia. ${ }^{4-7}$ Some of these changes have been correlated with disease progression. ${ }^{6}$

Mutations of the p53 tumour suppressor gene have been shown to be the most common genetic abnormality in human cancers. ${ }^{89}$ Most of these mutations alter the functional capabilities and conformation of the protein product. The normal wild type p53 protein has a very short half-life and is thus present in minute amounts in normal tissues and cells. It cannot, therefore, normally be detected by immunohistochemical methods. P53, however, has been detected immunohistochemically in histologically normal psoriatic epithelium and normal oesophageal mucosa obtained from the edge of resection specimens of invasive squamous esophageal cancer. ${ }^{1011}$ This is probably due to overexpression of wild type p53 in rapidly proliferating epithelium and is supported by the finding that wild type p53 levels increase in lymphocytes proliferating in response to mitogenic stimulation. ${ }^{12}$ This is consistent with the suggested role for p53 as a probable regulator of DNA repair, the loss of which 
might contribute to carcinogenesis. ${ }^{13}$ The conformational change produced by $\mathrm{p} 53$ gene mutation is thought to stabilise the protein, thereby prolonging the half-life of the protein which can be detected immunohistochemically by specific p53 antibodies. The increased expression of p53 protein has been shown in several human tumours ${ }^{14}$ and has also been correlated with mutation of the p53 gene. ${ }^{15-17}$ The accumulation of high concentrations of $\mathrm{p} 53$ is emerging as a potential marker for malignancy and in certain tumour types may be associated with a poor prognosis. ${ }^{18} 19$

\section{Methods}

One hundred and twenty six specimens were studied. These comprised 39 normal anal epithelia, 14 AIN 1, seven AIN 2, 20 AIN 3-all obtained from patients without demonstrable invasive disease- 12 AIN 3 specimens adjacent to invasive disease, and 34 anal squamous cancers. All specimens were obtained from the archival files of the histopathology departments of the Northern General Hospital, Sheffield, and St Mark's Hospital, London. The specimens had been previously fixed in $10 \%$ buffered formalin phosphate and paraffin wax embedded. The histopathological diagnosis in all specimens was reviewed by two independent observers (JHFS, SVP). There was good agreement between the two observers.

The specimens were analysed with a panel of two monoclonal antibodies DO-1 (courtesy of Professor DP Lane) and DO-7 (Novocastra Laboratories, England) and the rabbit polyclonal antibody CM-1 (courtesy of Professor DP Lane) produced against recombinant human p53 and permitting detection of $\mathrm{p} 53$ in routine formalin fixed histological material. ${ }^{2021}$ The antibodies were used in dilutions of 1 in 100,1 in 2000, and 1 in 4000 for DO-7, CM-1, and DO-1, respectively. DO-1 and DO-7 recognise epitopes between amino acids 1 and 45 at the $\mathrm{N}$ terminal end of both mutant and wild type p53 protein.

Sections $(5 \mu \mathrm{m})$ were cut, floated on poly1-lysine coated glass microscope slides, and air dried overnight at room temperature. Sections were dewaxed in xylene and hydrated through graded alcohols to deionised water. Immunohistochemical analysis was performed using a conventional three-layered streptavidin horseradish peroxidase technique. Endogenous peroxidase activity was blocked by a 5 minute incubation in $3 \%$ hydrogen peroxide, followed by incubation of the specimens in non-immune goat serum to block non-specific binding. The specimens were then incubated with the appropriate dilution of the primary antibody for 1 hour. Localisation of the primary antibody was achieved by means of the labelled streptavidin-avidin-biotin horseradish peroxidase technique (Dako LSAB kit, Dako Ltd, High Wycombe, Bucks) and 3',3-diaminobenzidine (activated with $3 \%$ hydrogen peroxide) as the chromogen. Washing in TRIS buffered saline ( $\mathrm{pH} 7 \cdot 6$ ) was carried out between each step. All incubations were carried out at room temperature. The sections were then lightly counterstained with Harris's hematoxylin, dehydrated in ascending grades of alcohol, and then mounted. A positive result is indicated by brown staining of the nucleus.

Sections of a colon adenocarcinoma known to express strongly mutant $\mathrm{p} 53$ protein were used as known positive controls. Nonimmune mouse serum was used in place of the primary antibodies in all sections of anal tissue and used as negative controls. Assessment of the specimens for p53 staining was made by two independent observers (OAO and SVP).

Specimens were considered to have stained positively for p53 if there was brown nuclear staining of the squamous epithelial cells with one or more of the p53 antibodies in at least $5 \%$ of the squamous epithelium. The intensity of staining was graded as 0 no staining; + minimal staining; ++ moderate staining; +++ strongly staining (table 1 ). There was complete agreement between the two observers with regard to those specimens that stained moderately or strongly for p53. In those specimens which stained less positively, and for which no agreement could be reached by the two observers, the specimens were graded as negatively staining.

Four $20 \mu \mathrm{m}$ thick sections from 126 specimens were cut, dewaxed in xylene and hydrated through graded alcohols. Genomic DNA extraction was carried out by proteinase $\mathrm{K}$ digestion and phenol extraction. All DNAs were analysed for HPV 16 DNA by polymerase chain reaction (PCR) using a pair of primers to the E6 open reading frame. ${ }^{22}$ The primer sequences are described below. PCR was performed on $200 \mathrm{ng}$ of genomic DNA in the presence of $20 \mathrm{mM} \mathrm{MgCl}$ with 2 units of Taq polymerase (Promega, UK), $50 \mathrm{pM}$ of each primer, buffer (Promega), and dNTPs to a reaction volume of $100 \mu \mathrm{l}$. Specific reaction conditions for PCR included 40 cycles of denaturation at $94^{\circ} \mathrm{C}$ for 1 minute, primer

Table 1 p53 staining in anal squamous cell neoplasia

\begin{tabular}{|c|c|c|c|c|c|}
\hline \multirow[b]{2}{*}{ Specimen } & \multirow[b]{2}{*}{ Total } & \multirow[b]{2}{*}{ No positive } & \multicolumn{3}{|c|}{ Intensity of staining } \\
\hline & & & + & ++ & +++ \\
\hline $\begin{array}{l}\text { Normal anal epithelium } \\
\text { AIN 1/HPV } \\
\text { AIN 2 } \\
\text { AIN 3-no invasion } \\
\text { AIN 3-invasion } \\
\text { Anal cancer }\end{array}$ & $\begin{array}{r}39 \\
14 \\
7 \\
20 \\
12 \\
34\end{array}$ & $\begin{array}{r}0 \\
5 \\
6 \\
12 \\
9 \\
23\end{array}$ & $\begin{array}{l}- \\
z \\
-\end{array}$ & $\begin{array}{l}-5 \\
6 \\
3 \\
2\end{array}$ & $\begin{array}{r}- \\
\overline{-} \\
9 \\
21\end{array}$ \\
\hline
\end{tabular}


annealing at $55^{\circ} \mathrm{C}$ for 1.5 minutes, and primer extension at $72^{\circ} \mathrm{C}$ for 3 minutes. Beta globin primers were used as controls for each sample to ensure that template DNA amplification was taking place. The amplified reaction products were visualised following electrophoresis in $1.5 \%$ agarose gels using ethidium bromide staining on an ultraviolet light box. Positive control DNA derived from CaSki cells was used throughout. Negative control samples contained sterile water in place of template DNA. The sequences of primers used are as follows:

HPV 16
Primer A 5'-TCA AAA GCC ACT GTG TCC TG-3'
Position 421-440
Primer B 5'-CGT GTT CTT GAT GAT CTG CAA-3'
Position 540-521

\section{Results}

CONTROLS AND NORMAL ANAL EPITHELIUM

No reactivity was seen on any of the negative controls when immunostaining was carried out with the primary antibody replaced by normal mouse serum. All specimens of normal anal epithelium were negative with all of the three p53 antibodies. Sections of colon adenocarcinoma used as positive controls reacted strongly with all three antibodies. Staining was nuclear, involving over $50 \%$ of the tumour cells. Stroma and non-malignant cells did not stain.

\section{LOW GRADE AIN}

The results of immunohistochemical evaluation of low grade AIN lesions showed that p53 was expressed at low concentrations in $35 \cdot 7 \%(5 / 14)$ of AIN 1 specimens and $85 \cdot 7 \%$ $(6 / 7)$ of AIN 2 specimens. Staining was
Immunohistochemical staining for $p 53$ protein in (A) invasive anal squamous cancer; $(B)$ $A I N$ 3; (C) $A I N$ 2, with the monoclonal antibodies $D O-1, D O-7$, and the polyclonal antibody CM-1, respectively. The reaction product is brown

(counterstain Harris's

haematoxylin). Staining is intense, nuclear, and diffuse in anal cancer and AIN 3. Staining in AIN 2 is also nuclear, although it is much weaker and focally distributed.

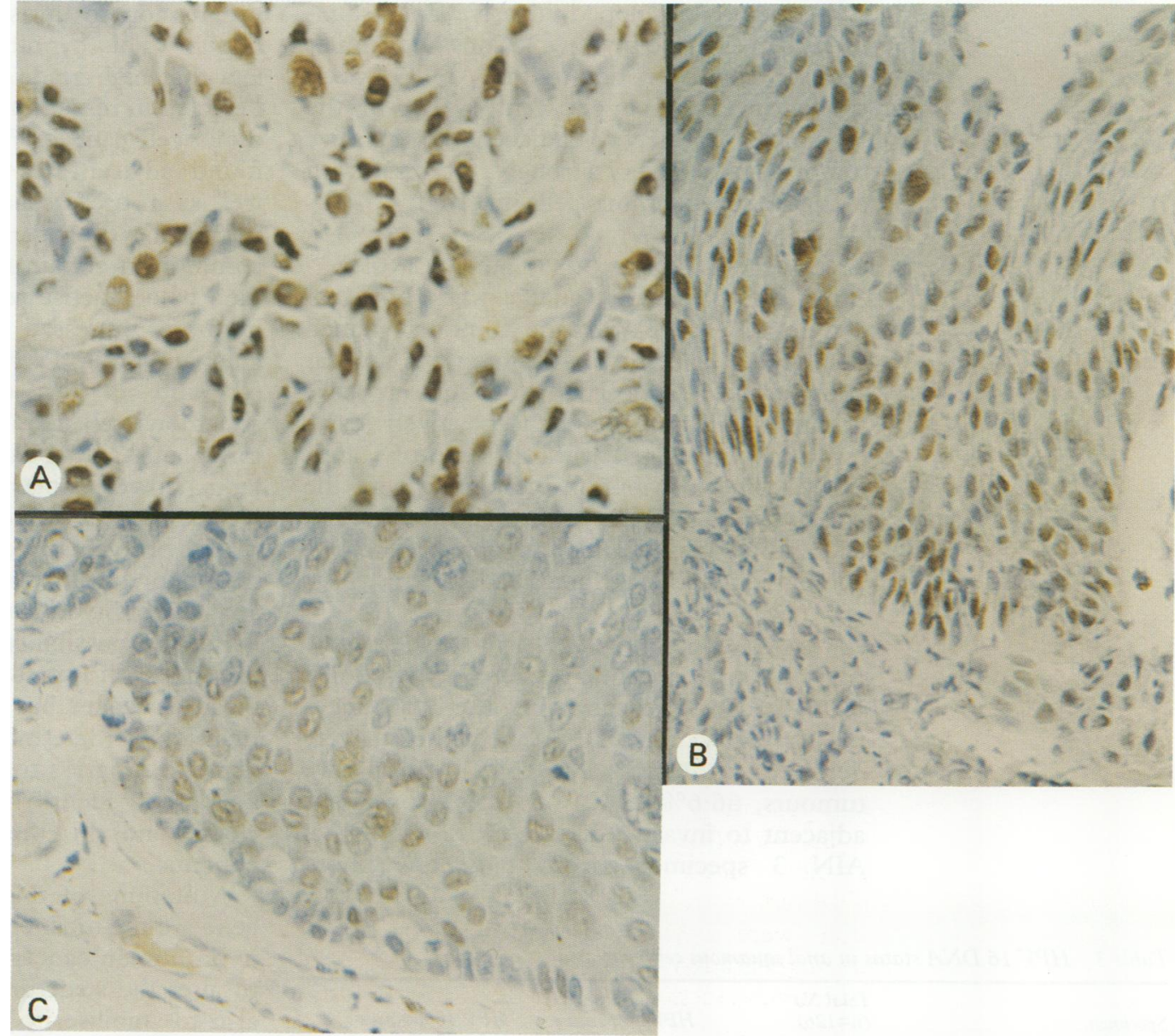

Table 2 Staining with p53 antibodies in anal squamous cell neoplasia

\begin{tabular}{lccccc}
\hline Specimen & $\begin{array}{l}\text { Total No } \\
\text { positive } \\
(n=55)\end{array}$ & $\begin{array}{l}\text { DO-7 } \\
\text { positive } \\
(\%)\end{array}$ & $\begin{array}{l}\text { DO-1 } \\
\text { positive } \\
(\%)\end{array}$ & $\begin{array}{l}\text { CM-1 } \\
\text { positive } \\
(\%)\end{array}$ & $\begin{array}{l}\text { All antibodies } \\
\text { positive } \\
(\%)\end{array}$ \\
\hline Normal anal epithelium & 0 & 0 & 0 & 0 & 0 \\
AIN 1/HPV & 5 & $4(80)$ & $4(80)$ & $5(100)$ & $4(80)$ \\
AIN 2 & 6 & $6(100)$ & $5(83)$ & $6(100)$ & $5(83)$ \\
ANN 3-no invasion & 12 & $12(100)$ & $11(91)$ & $11(91)$ & $11(91)$ \\
AIN 3-invasion & 9 & $9(100)$ & $9(100)$ & $9(100)$ & $9(100)$ \\
Anal cancer & 23 & $21(91)$ & $20(90)$ & $22(95)$ & $20(90)$ \\
\hline
\end{tabular}


exclusively nuclear, weak in intensity, involving at least $5 \%$ of the dysplastic squamous epithelium (Figure). At least $80 \%$ of the specimens stained positively with all 3 antibodies (table 2). There was no staining of the stroma and normal squamous epithelial cells in the specimens.

HIGH GRADE AIN

Analysis of p53 immunostaining in the two groups of AIN 3 specimens showed that a significant number stained positively with the p53 antibodies (table 2). In AIN 3 specimens obtained from patients without demonstrable invasive disease in the primary biopsy material, $60 \%(12 / 20)$ of the specimens stained positively for p53 protein. Staining was exclusively nuclear, involving over $50 \%$ of the squamous cells in seven specimens, and $10-15 \%$ of the squamous cells in five specimens (Figure). During a mean follow up period of 12 months (range 3-18 months), two patients with positive staining specimens subsequently developed invasive anal squamous cancer. The invasive lesions had similar staining characteristics to the AIN 3 specimens. Seventy five per cent $(9 / 12)$ of the specimens of AIN 3 adjacent to invasive tumour stained very strongly for $\mathrm{p} 53$, with over $50 \%$ of squamous cells involved.

INVASIVE ANAL SQUAMOUS CELL CARCINOMA Analysis of 34 invasive anal cancers show that about $67 \%(23 / 34)$ of the tumours stained strongly for p 53 protein. Staining was nuclear and involved almost all the tumour cells (figure). At least $90 \%$ of the positively staining tumours reacted with all three p53 antibodies. The distribution of staining with the antibodies was similar, although the intensity of staining was slightly greater with DO-1 compared with CM-1 and DO-7.

HPV STATUS AND ABERRANT P53 EXPRESSION All 126 anal specimens were analysed for HPV 16 DNA status using the PCR technique. HPV 16 DNA sequences were detected in $76.5 \%(26 / 34)$ of invasive tumours, $66 \cdot 6 \%(8 / 12)$ of AIN 3 specimens adjacent to invasive disease, $75 \%(15 / 20)$ of AIN 3 specimens from patients without

Table 3 HPV 16 DNA status in anal squamous cell neoplasia

\begin{tabular}{llcl}
\hline Specimen & $\begin{array}{l}\text { Total No } \\
(n=126)\end{array}$ & HPV 16 positive & HPV 16 negative \\
\hline Normal anal epithleium & 39 & 0 & 39 \\
AIN 1/HPV & 14 & 4 & 10 \\
AIN 2 & 7 & 3 & 4 \\
AIN 3-no invasion & 20 & 15 & 5 \\
ANN 3-invasion & 12 & 8 & 4 \\
Anal cancer & 34 & 26 & 8 \\
\hline
\end{tabular}

Table 4 HPV 16 status in p53 positively staining specimens $(n=55)$

\begin{tabular}{lccl}
\hline Specimen & Total No p53 positive & HPV 16 positive & HPV 16 negative \\
\hline Normal anal epithleium & 0 & 0 & 0 \\
AIN 1/HPV & 5 & 2 & 3 \\
AIN 2 & 6 & 2 & 4 \\
AIN 3-no invasion & 12 & 9 & 3 \\
AIN 3-invasion & 9 & 7 & 2 \\
Anal cancer & 23 & 16 & 7 \\
\hline
\end{tabular}

demonstrable invasive disease, $42 \cdot 8 \%$ (3/7) of AIN 2 and $28 \cdot 5 \%(4 / 14)$ of AIN 1 specimens. None of the specimens of normal anal epithelium was positive for HPV 16 DNA (table 3). A total of $43.6 \%$ (55) specimens stained positively for $\mathrm{p} 53$. Of these, 36 were HPV 16 positive and 19 were HPV 16 negative (table 4).

Statistical analysis examining the correlation between p53 staining and the HPV DNA status in all the neoplastic anal specimens was performed using the $\chi^{2}$ test (with a significance of $p<0.05$ ). There was no correlation between p53 positivity and HPV 16 DNA status.

\section{Discussion}

Intraepithelial neoplastic lesions of the anus (AIN) were first described a decade ago. ${ }^{23}$ The natural history of these lesions is unknown, although possible parallels between AIN and cervical intraepithelial neoplasia (CIN) have been suggested with regard to progression to invasive squamous cell carcinoma. ${ }^{24}$ This hypothesis is supported by the fact that high grade AIN 3 lesions have been detected in resection specimens for anal squamous cell cancer. ${ }^{25} 26$ The lesions have been found adjacent to the invasive tumours as well as in areas separated from the tumours by normal mucosa. AIN seems to be fairly common in certain risk groups: homosexual men who practise receptive anal intercourse; immunosuppressed organ transplant recipients; and group IV HIV seropositive individuals, and as part of multifocal anogenital squamous cell neoplasia. ${ }^{25} 2728$ In view of the rarity of anal squamous neoplasia (3\% of large bowel cancers), ${ }^{29}$ most of the AIN lesions seem to regress or remain static. This poses problems for their management as treatment of all lesions may result in avoidable morbidity in some patients. On the other hand, the possibility that a small number of patients with untreated AIN may progress to invasive cancer has to be considered. How, then, do we determine which AIN lesions are likely to progress to invasive cancer? Ideally, a marker identifying abnormal anal cells would aid in the management of such patients.

Mutations of the p53 tumour suppressor gene are the most common genetic abnormality in human cancers. ${ }^{8}$ These mutations seem to alter the structure of the $\mathrm{p} 53$ protein and also to stabilise it, leading to increased concentrations of mutant p53 protein in cells. Furthermore, certain mutant $\mathrm{p} 53$ proteins act as dominant transforming oncogenes. ${ }^{30}$ Recent studies have shown that in cervical tumours and cell lines, as well as in a small series of anal tumours, there seems to be an inverse relation between the presence of p53 mutations and oncogenic HPV sequences: only HPV negative tumours seem to contain mutations of the $\mathrm{p} 53$ gene. ${ }^{6} 3132$ This suggests that an alteration in the function of $\mathrm{p} 53$, either by mutation or binding to HPV encoded proteins, is implicated in the pathogenesis of anogenital neoplasia. 
The results of our study show that increased p 53 protein concentrations occur in high grade $A I N$ and invasive anal squamous cell carcinomas. The similarity in the pattern of distribution of p53 concentrations in invasive tumours and adjacent AIN 3 lesions suggest that a field effect phenomenon may be operating. Furthermore, in two specimens of AIN 3 obtained from patients without demonstrable invasive disease, which stained strongly for the $\mathrm{p} 53$ protein, the patients subsequently developed invasive anal squamous cell carcinomas which had a similar staining pattern to that of the AIN 3 specimens. These results suggest that mutations of the p53 gene (leading to expression of high concentration of mutant $\mathrm{p} 53$ protein) may have a role in the pathogenesis of anal squamous neoplasia. The accumulation of mutant p53 protein may also possibly serve as a marker of likely disease progression from AIN 3 to invasive lesions. Long term follow up of the AIN 3 lesions, however, are required to confirm these results.

These results are similar to those of studies which have examined p53 expression in squamous neoplasia at other sites. These studies have shown increased concentrations of the p53 protein in oesophageal, skin, and head and neck squamous cell carcinomas. ${ }^{1133-36}$ Furthermore, some of these studies have shown a close correlation between increased concentrations of $\mathrm{p} 53$ protein and mutations of the p53 gene locus. ${ }^{33} 34$ Increased p 53 concentrations have also been shown in dysplastic and normal epithelium obtained from patients with $\mathrm{p} 53$ positive invasive squamous cell carcinomas. ${ }^{114}$

The presence of increased $\mathrm{p} 53$ protein concentrations in HPV positive AIN and invasive tumours (table 4 ) is surprising, as current evidence suggests that there is an inverse relation between the presence of $\mathrm{p} 53$ mutations and oncogenic HPV sequences. The E6 oncogenic protein of HPV 16 and 18 has been shown to complex with wild type p53 protein, accelerating its degradation, and thereby nullifying the tumour suppressor effects of the wild type p53 protein. ${ }^{3738}$ In HPV negative tumours it is thought that mutations of the p53 gene leads to loss of function of the wild type allele. The results from recent studies, however, suggest that the relation between HPV infection and p53 mutation in anogenital neoplasia may not be quite so clear cut. ${ }^{39} 40$ These studies suggest that there is no obvious association between the presence or absence of HPV sequences and mutations or allelic loss at the p53 gene locus.

We do not think that the results of the present study are due to non-specific cross reaction as antibodies to different epitopes on the p53 molecule were used. The results with these antibodies correlated strongly with each other (table 2) and were consistently repeatable. Further investigation into the status of the p53 gene in anal squamous neoplasia, however, is required. We are currently sequencing the p53 gene locus in the specimens examined in the present study.
We thank Professor DP Lane (CRC Research Laboratories, University of Dundee), for the gift of the p53 antibodies, DO- 1 and $\mathrm{CM}-1$. We also thank Mr JMA Northover and $\mathrm{Mr}$ $\mathrm{K}$ Miller for providing the specimens from St Mark's Miller for provic
Hospital, London.

1 Zur Hausen H. Papillomaviruses in human cancers. Mol Carcinogen 1989;1:147-50.

2 Palmer JG, Scholefield JH, Coates PJ, et al. Anal squamous cell carcinoma and human papilloma viruses. Dis Colon Rectum 1989;32:1016-22.

3 Zur Hausen $H$. Papillomaviruses as carcinoma viruses: In: Klein G, ed. Advances in viral oncology. New York: Raven Press, 1989:1-26.

4 Pinion SB, Kennedy JH, Miller RW, Maclean AB Oncogene expression in cervical intraepithelial neoplasia and invasive cancer of the cervix. Lancet 1991;337: 819-20.

5 Riou G, Barrios M, Le MG, George M, Le Doussal V, Haie C. c-myc proto-oncogene expression and prognosis in early carcinoma of the cervix. Lancet 1987;i: sis in

6 Crook T, Wrede D, Tidy J, Scholefield JH, Crawford L, Vousden KH, Status of c-myc, p53 and retinoblastoma genes in human papillomavirus positive and negative squamous cell carcinomas of the anus. Oncogene 1991;6:1251-7.

7 Ogunbiyi OA, Scholefield JH, Rogers K, Sharp F, Smith JHF, Polacarz SV. c-myc oncogene expression in anal squamous neoplasia. f Clin Pathol 1992;45:889-93.

8 Hollstein M, Sidransky D, Vogelstein S, Harris CC. p53 mutations in human cancers. Science 1991;253:49-53.

9 Nigro JM, Baker SJ, Preisinger AC, et al. Mutations in the p53 gene occur in diverse human tumour types. Nature p53 gene occur in

10 Tadiani G, Cerri A, Crosti L, Cattoretti G, Berti E. p53 and oncogene expression in psoriasis. Acta Dermatol Venereol 1989;146(Suppl):33-5.

11 Sasano H, Goukon Y, Nishihira T, Nagura H. In situ hybridisation and immunohistochemistry of p53 tumour suppressor gene in human esophageal carcinoma. $A m \mathcal{F}$ Pathol 1992;141:545-50.

12 Rivas CI, Wisniewski D, Strife A, et al. Constitutive expression of p53 in enriched normal human marrow blast cell population. Blood 1992;79:1982-6.

13 Kastan MB, Onyekwere O, Sidransky D, Vogelstein B, Craig RW. Participation of p53 protein in the cellular response to DNA damage. Cancer Res 1991;51: response

14 Bartek J, Bartkova J, Vojtesek B, et al. Aberrant expression of the p 53 oncoprotein is a common feature of a wide spectrum of human malignancies. Oncogene 1991;6: 1699-703.

15 Bennett WP, Hollstein MC, He A, et al. Archival analysis of p53 genetic and protein alterations in Chinese oesophageal cancer. Oncogene 1991;6:1779-84.

16 Bartek J, Iggo R, Gannon J, Lane. DP. Genetic and immunochemical analysis of mutant p53 in human breast cancer cell lines. Oncogene 1990;5:893-9.

17 Rodrigues NR, Rowan A, Smith MEF, et al. p53 mutations in colorectal cancer. Proc Natl Acad Sci USA tions in colorectal

18 Cattoretti G, Rilke F, Andreola S, D'Amato L, Delia D. p53 expression in breast cancer. Int $\mathcal{F}$ Cancer 1988; 41:178-83.

19 Hall P, Ray A, Lemoine NR, Midgley CA, Krauz T, Lane DP. p53 immunostaining is a marker of malignancy in diagnostic cytopathology. Lancet 1991;338: 513.

20 Vojtesek B, Bartek J, Midgley CA, Lane DP. An immunochemical analysis of the human nuclear phosphoprotein p53. New monoclonal antibodies and epitope mapping using recombinant p53. $\mathcal{f}$ Immunol Methods 1992;151: using recor

21 Midgley CA, Fisher CJ, Bartek J, Vojtesk B, Lane D, Barnes DM. Analysis of p53 expression in human tumours: an antibody raised against human p53 in Escherichia coli. $\mathcal{F}$ Cell Sci 1992;101:183-9.

22 Young LS, Bevan IS, Johnson MA, et al. The polymerase chain reaction: A new epidemiological tool for investigating cervical human papillomavirus infection. $\mathrm{Br} \mathrm{Med}$ f 1989;298:14-18.

23 Fenger C, Nielsen VT. Dysplastic changes in the anal canal epithelium in minor surgical specimens. Acto Pathol Microbiol Scand 1981;89:463-5.

24 Scholefield JH, Sonnex C, Tablot IC, et al. Anal and cervical intraepithelial neoplasia: Possible parallel. Lancet vical intraepithei

25 Palefsky JM, Gonzales J, Greenblatt RM, Ahn DK Hollander $H$. Anal intraepithelial neoplasia and anal papillomavirus infection among homosexual males with papillomavirus infection among homosexual males
group IV HIV disease. $¥ A M A$ 1990;263:2911-16.

26 Fenger C, Nielsen V. Precancerous changes in the anal canal epithelium in resection specimens. Acta Pathol Microbiol Scand 1986;94:63-9. 
27 Wexner SD, Milsom JW, Dailey TH. The demographics of anal cancers are changing: Identification of a high risk population. Dis Colon Rectum 1987;30:942-6.

28 Penn I. Cancers of the anogenital region in renal transplant recipients. Analysis of 65 cases. Cancer 1986;58: 611-16.

29 Morson BC. The pathology and results of treatment of squamous cell carcinoma of the anal canal and anal margin. Proc Roy Soc Med 1960;53:416-20.

30 Levine AJ, Momand J, Finlay CA. The p53 tumour supressor gene (review article). Nature, 1991;351:453-6.

31 Crook T, Wrede D, Tidy JA, Mason WP, Evans DJ Vousden K. Clonal p53 mutation in primary cervical cancer: association with human papillomavirus-negative cancer: association with human pap

32 Wrede D, Tidy JA, Crook T, Lane D, Vousden KH Expression of RB and $\mathrm{p} 53$ proteins in HPV-positive an HPV negative cervical carcinoma cell lines. Mol Carcinogen, 1991;4:171-5.

33 Bennett WP, Hollstein MC, He A, et al. Archival analysis of $\mathrm{p} 53$ genetic and protein alterations in Chinese esophageal cancer. Oncogene 1991;6:1779-84.
34 Gusterson BA, Anbazhagan R, Warren W, et al. Expression of $\mathrm{p} 53$ in premalignant and malignant squamous epithelium. Oncogene 1991;6:1785-9.

35 Ogden GR, Kiddie RA, Lunny DP, Lane DP. Assessment of p53 protein expression in normal benign, and malignant oral mucosa. $\mathcal{F}$ Pathol 1992;166:389-94.

36 McGregor JM, Levison DA, MacDonald DM, Yu CC Papillomaviruses, p53, and cervical cancer. Lancet 1992;339:1351.

37 Werness BA, Levine AJ, Howley PM. Association of human papillomavirus types 16 and $18 \mathrm{E} 6$ proteins with p53. Science 1990;248:76-9.

38 Scheffner $M$, Werness BA, Huibregtse JM, Levine AJ Howley PM. The E6 oncoprotein encoded by human papillomavirus types 16 and 18 promotes the degradapapillomavirus types 16 and 18 prom

39 Russell SEH, Lowry WS, Atkinson RJ, Hickey I Homozygosity of the short arm of chromosome 17 in cervical carcinoma. Cancer Letts 1992;62:242-7.

40 Borresen AL, Helland A, Nesland J, Holm R, Trope C, Kearn J. Papillomaviruses, p53 and cervical cancer. Lancet 1992;339:1350-1. 